\title{
Pengaruh Kapasitas Sumber Daya Manusia, Pemanfaatan Teknologi Informasi dan Penerapan Sistem Akuntansi Keuangan Daerah terhadap Kualitas Laporan Keuangan Daerah (Pada SKPD Kabupaten Minahasa Selatan)
}

\author{
FERNANDO ANDREAS MAMAHIT ${ }^{1}$, JULLIE J SONDAKH ${ }^{2}$, VENTJE ILAT ${ }^{3}$ \\ ${ }^{1,2,3}$ Program Magister Akutansi, Fakultas Ekonomi dan Bisnis Universitas Sam Ratulangi \\ e-mail : nanando.jo@gmail.com
}

\begin{abstract}
Gaining a regional autonomy by local government means it is the authority for them to manage their own households and lesser interference of the central government. The local government has the right and the broad authority to use the financial resources provided under the requirement. However, with such broad authority, it does not mean that local governments can use the financial resource without any clear direction and purpose. This study is intended to analyze and obtain evidence of the influence of human resource capacity, utilization of information technology and the application of financial accounting system towards the quality of local government financial statements in South Minahasa. This is a quantitative research. Primary data were collected by questionnaires. They were distributed to financial managers (financial administration officers, finance technical enforcement officers and the treasurer) in the Working Units of South Minahasa Regency. The population in this research is 153 finance staff in the Working Unit of South Minahasa Regenc. Respondents were Inspectorate, regional secretary, council secretariat, services and office. 82 respondents were participated within this research. Data was analysed by multiple regression analysis, $f$ test and $t$ test. The result of this research found that Human Resource Capacity, Utilization of information technology and aplication area of financial accounting system simultaneously and significantly influence the quality of Financial Statement information of local goverment in South Minahasa Regency.
\end{abstract}

Keywords : the quality of financial statements, human resource capacity, utilization of information technology, financial accounting system implementation.

Abstrak. Dengan adanya otonomi daerah diberikan kewenangan yang luas untuk mengurus rumah tangganya sendiri dengan sesedikit mungkin campur tangan pemerintah pusat. Pemerintah daerah mempunyai hak dan kewenangan yang luas untuk menggunakan sumber-sumber keuangan yang dimilikinya sesuai dengan kebutuhan. Namun demikian dengan kewenangan yang luas tersebut, tidaklah berarti bahwa pemerintah daerah dapat menggunakan sumber-sumber keuangan yang dimilikinya sekehendaknya, tanpa arah dan tujuan yang jelas. Penelitian ini bertujuan untuk menganalisis dan memperoleh bukti pengaruh kapasitas sumber daya manusia, pemanfaatan teknologi informasi dan penerapan sistem akuntansi keuangan daerah pada pemerintah Kabupaten Minahasa Selatan. Jenis penelitian ini ditinjau dari tujuan penelitian merupakan penelitian kuantitatif asosiatif dengan metode analisis linier berganda Lokasi penelitian dilakukan di Pemerintah Kabupaten Minahasa Selatan. Sumber data yang digunakan dalam penelitian ini adalah data primer. Pengumpulan data dilakukan melalui penyebaran kuesioner kepada Pengelola Keuangan (Pejabat Penatausahaan Keuangan, Pejabat Pelaksana Teknis Keuangan dan Bendahara Pengeluaran) pada Satuan Kerja Perangkat daerah (SKPD) di Pemerintah Kabupaten Minahasa Selatan. Populasi dalam penelitian ini adalah 153 pengelola keuangan yang tersebar pada Satuan Kerja Perangkat Daerah (SKPD) yang berada di Pemerintah Kabupaten Minahasa Selatan antara lain :Inspektorat, Sekretariat Daerah, Sekretariat Dewan, Dinas, Badan, Kantor, yang menjadi sampel dalam penelitian ini adalah sebanyak 82 responden. Data dianalisis menggunakan analisis regresi linier berganda (multiple regresi) Uji F dan Uji-t. Hasil penelitian menunjukkan bahwa Kapasitas Sumber Daya Manusia, Pemanfaatan Teknologi Informasi dan Penerapan Sistem Akuntansi Keuangan Daerah secara simultan memiliki pengaruh yang signifikan terhadap Kualitas Informasi Laporan Keuangan Pemerintah Daerah (LKPD) Pemerintah Kabupaten Minahasa Selatan.

Kata Kunci: Kualitas Laporan Keuangan, Kapasitas Sumber Daya Manusia, Pemanfaatan Teknologi Informasi, Penerapan Sistem Akuntansi Keuangan Daerah 


\section{Pendahuluan}

Undang-undang Nomor 32 Tahun 2004 tentang Pemerintah Daerah dan Undang-Undang Nomor 33 Tahun 2004 tentang Perimbangan Keuangan antara Pemerintah Pusat dan Pemerintah Daerah merupakan landasan utama diberlakukannya otonomi daerah di Indonesia. Dengan adanya otonomi ini, daerah diberikan kewenangan yang luas untuk mengurus rumah tangganya sendiri berdasarkan hak dan kewenangan dalam menggunakan dan mengelola sumber-sumber keuangan yang dimiliki sesuai dengan kebutuhan berdasarkan kewenangan yang diberikan oleh pemerintah pusat.

Sebagai salah satu bentuk pertanggung-jawaban dalam penyelenggaraan pemerintahan yang diatur dalam Undang-Undang Nomor 17 Tahun 2003 tentang Keuangan Negara dan Undang-Undang Nomor 23 Tahun 2014 tentang Pemerintahan Daerah yang merupakan upaya konkrit untuk mewujudkan transparansi dan akuntabilitas pengelolaan keuangan pemerintah, baik pemerintah pusat maupun pemerintah daerah adalah dengan menyampaikan laporan pertanggungjawaban berupa laporan keuangan. Laporan keuangan pemerintah yang dihasilkan harus memenuhi prinsip-prinsip tepat waktu dan disusun dengan mengikuti Standar Akuntansi Pemerintahan sesuai dengan Peraturan Pemerintah Nomor 71 Tahun 2010. Laporan keuangan merupakan bentuk pertanggungjawaban pemerintah atas pelaksanaan Anggaran Pendapatan dan Belanja Nasional/Daerah (APBN/D) berupa laporan realisasi anggaran, laporan perubahan saldo anggaran lebih (LPSAL), laporan operasional, neraca, laporan arus kas (LAK), dan catatan atas laporan keuangan.

Peraturan Menteri Dalam Negeri (Permendagri) nomor 21 Tahun 2011 menyebutkan, bahwa untuk tujuan akuntabilitas atas pengelolaan dana-dana yang dikelola oleh provinsi atau kabupaten/kota diwajibkan menyiapkan laporan keuangan pemerintah daerah. Salah satu indikator utama yang menunjukkan keberhasilan pemerintah dalam mempertanggungjawabkan pengelolaan anggarannya adalah dengan terwujudnya laporan keuangan yang berkualitas. Pemerintah Kabupaten/Kota maupun Provinsi diwajibkan menerbitkan Laporan Keuangan Pemerintah Daerah sebagai bentuk pertanggungjawaban telah berakhirnya tahun anggaran dan wajib diaudit oleh Badan Pemeriksa Keuangan Republik Indonesia (BPK-RI).

Berdasarkan hasil pemeriksaan BPK RI Perwakilan Provinsi Sulawesi Utara terhadap Laporan Keuangan Pemerintah Daerah Kabupaten Minahasa Selatan masih ditemukan permasalahan- permasalahan mendasar yang mempengaruhi laporan keuangan diantaranya: pertama; tidak tertibnya para bendahara dalam melapor dan mengembalikan kas per 31 Desember. Kedua; BPK juga menemukan pengelolaan persediaan yang tidak memadai. Ketiga; adanya belanja yang belum dipertanggungjawabkan serta tidak didukung bukti yang memadai. Keempat; BPK juga menemukan adanya aset yang tidak didukung dengan bukti yang memadai. Kelima; Kebijakan kapitalis aset yang tidak memadai. Keenam; BPK menemukan adanya pengelolaan utang yang tidak memadai pengelolaan persedian yang tidak memadai. Ketujuh; BPK juga menemukan penyajian saldo silpa yang tidak memadai. Kedelapan; Realisasi belanja yang tidak sesuai peruntukan atau tidak tertib anggaran. Kesembilan; Penatausahaan pendapatan yang tidak memadai. Dan yang terakhir kekurangan pekerjaan fisik dan belum dikenakan denda keterlambatan. Permasalahan yang dikemukakan diatas tidak sesuai dengan PP 71 tahun 2010 bahwa laporan keuangan harus memenuhi syarat yakni : Relevan, andal, dapat dibandingkan dan dapat dipahami,sehingga opini yang diberikan oleh BPK RI atas LKPD Pemerintah Kabupaten Minahasa Selatan adalah Wajar Dengan Pengecualian (WDP).

Permasalahan yang terjadi di Kabupaten Minahasa Selatan diakibatkan oleh banyak faktor diantaranya; kapasitas sumber daya manusia, pemanfaatan teknologi informasi, penerapan sistem akuntansi keuangan daerah, hal tersebut berdasarkan hasil penelitian terdahulu 
kebanyakan berpengaruh positif dan signifikan terhadap kualitas laporan keuangan. Sesuai dengan permasalahan yang terjadi di Kabupaten Minahasa Selatan, variabel kapasitas sumber daya manusia, pemanfaatan teknologi informasi dan penerapan sistem akuntansi keuangan daerah yang paling mempengaruhi terhadap kualitas laporan keuangan daerah.

Tujuan dari penelitian ini adalah :

1. Menganalisis Pengaruh Kapasitas Sumber Daya Manusia terhadap Kualitas Laporan Keuangan Daerah Kabupaten Minahasa Selatan.

2. Menganalisis Pengaruh Pemanfaatan Teknologi Informasi terhadap Kualitas Laporan Keuangan Daerah Kabupaten Minahasa Selatan.

3. Menganalisis Pengaruh Penerapan Sistem Akuntansi Keuangan Daerah terhadap Kualitas Laporan Keuangan Daerah Kabupaten Minahasa Selatan

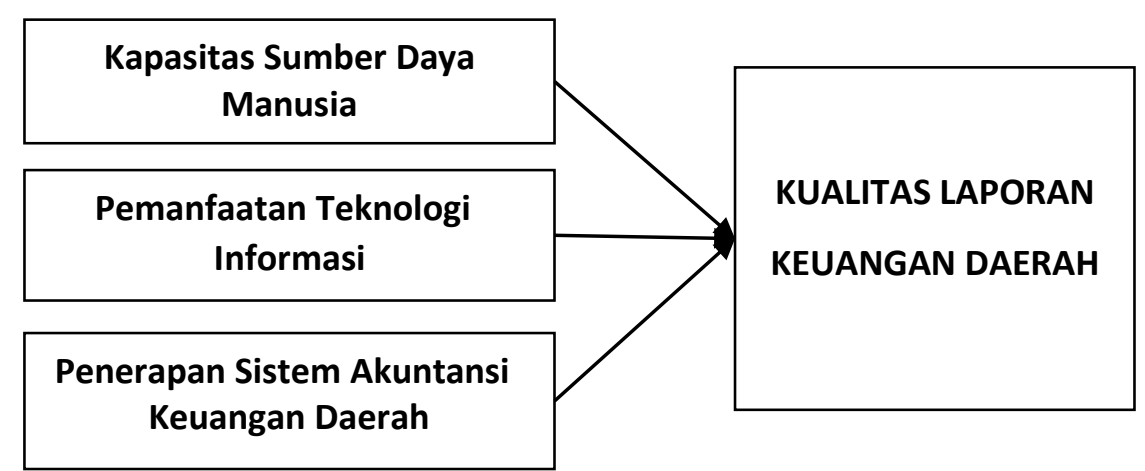

Gambar 1. Kerangka Pemikiran

Agar dapat menyediakan informasi yang berguna dan bermanfaat bagi pihak-pihak yang berkepentingan, maka informasi yang disajikan dalam pelaporan keuangan harus memenuhi karakteristik kualitatif sehingga dapat digunakan dalam pengambilan keputusan (Hapsari, 2007). Atril dan McLaney (1991) dalam Saidin (2007) menyebutkan kriteria yang harus dimiliki oleh pelaporan keuangan agar dapat memenuhi kebutuhan pengguna, diantaranya adalah relevan, andal, dapat dibandingkan, dapat dimengerti, tepat waktu dan biaya/ manfaat. Ditegaskan bahwa relevan dan dapat diandalkan dari pelaporan keuangan dapat membantu dalam menghasilkan informasi yang bermanfaat, namun jika laporan keuangan tidak dapat dibandingkan, tidak dapat dimengerti dan tidak tepat waktu, biaya yang lebih besar dari manfaat maka akan mengurangi manfaatnya.

Manusia adalah unsur terpenting dalam keberhasilan suatu organisasi. Karena, manusia merupakan elemen yang selalu ada dalam setiap organisasi, yang membuat tujuan-tujuan, inovasi, dan mencapai tujuan organisasi, serta manusia merupakan satu-satunya sumber daya yang membuat sumber daya lainnya bekerja dan berdampak langsung terhadap kesejahteraan organisasi Susanto (1997) dalam Tangkilisan (2005:189).

Teknologi Informasi (information technology) biasa di sebut $T I, I T$, atau, infotech. teknologi informasi dapat di artikan sebagai teknologi yang mampu membantu orang untuk menciptakan, menyimpan, mengubah, dan menyebarkan informasi (Kadir, 2006). Secara sederhana teknologi informasi dapat dikatakan sebagai ilmu yang diperlukan untuk mengelola informasi agar informasi tersebut dapat dicari dengan mudah dan akurat.

Peraturan Pemerintah Republik Indonesia Nomor 65 Tahun 2010 tentang Sistem Informasi Keuangan Daerah (SIKD) menyebutkan bahwa Sistem Informasi Keuangan Daerah adalah suatu sistem yang mendokumentasikan, mengadministrasikan, serta mengolah data pengelolaan keuangan daerah dan data terkait lainnya menjadi informasi yang disajikan kepada masyarakat dan sebagai bahan pengambilan keputusan dalam rangka perencanaan, pelaksanaan, dan pelaporan pertanggungjawaban pemerintah daerah. Informasi 
keuangan daerah adalah segala informasi yang berkaitan dengan keuangan daerah yang diperlukan dalam rangka penyelenggaraan sistem informasi keuangan daerah. Dengan demikian sistem informasi keuangan daerah dapat didefinisikan sebagai suatu sistem pengelompokan, penggolongan, pencatatan dan pemprosesan aktivitas keuangan pemerintah daerah kedalam sebuah laporan keuangan sebagai suatu informasi yang dapat digunakan oleh pihak tertentu dalam pengambilan keputusan. Sedangkan penerapan sistem akuntansi keuangan daerah adalah penerapan sistem informasi akuntansi tesebut oleh masing-masing satuan kerja perangkat daerah dalam proses penyusunan laporan keuangan pemerintah daerah.

\section{Metode Penelitian}

Penelitian ini menggunakan jenis kuantitatif asosiatif. Menurut Sugioyono (2015) metode kuantitatif dapat diartikan sebagai metode penelitan yang berlandaskan pada filsafat positivisme, digunakan untuk meneliti pada populasi atau sampel tertentu, pengumpulan data menggunakan instrumen penelitian, analisis data bersifat kuantitatif/statistik, dengan tujuan untuk menguji hipotesis yang telah ditetapkan. Untuk menguji kapasitas sumber daya manusia $\left(X_{1}\right)$, pemanfaatan teknologi informasi $\left(X_{2}\right)$, penerapan sistem akuntansi keuangan daerah $\left(X_{3}\right)$ sebagai variabel independen terhadap kualitas kualitas laporan keuangan daerah $(\mathrm{Y})$ sebagai variabel dependen. Teknik analisis yang digunakan adalah analisis regresi linear berganda.

Penelitian ini dilakukan pada SKPD Kabupaten Minahasa Selatan Populasi dalam penelitian ini adalah 153 pengelolah keuangan yang tersebar pada Satuan Kerja Perangkat Daerah (SKPD) yang berada di Pemerintah Kabupaten Minahasa selatan antara lain :Inspektorat, Sekretariat Daerah, Sekretariat Dewan, Dinas, Badan, Kantor. Dari populasi sebanyak 153 pengelolaan keuangan yang ada di 51 SKPD tersebut akan diambil sejumlah sampel dengan menggunakan rumus Slovin dan mendapat sampel berjumlah 82 .

Menurut Tjiptoherijanto (1998), untuk menilai kapasitas dan kualitas sumber daya manusia dalam melaksanakan suatu fungsi, termasuk akuntansi, dapat dilihat dari level of responsibility dan kompetensi sumber daya tersebut. Tanggung jawab dapat dilihat dari atau tertuang dalam deskripsi jabatan. Deskripsi jabatan merupakan dasar untuk melaksanakan tugas dengan baik. Tanpa adanya deskripsi jabatan yang jelas, sumberdaya tersebut tidak dapat melaksanakan tugasnya dengan baik. Sedangkan kompetensi dapat dilihat dari latar belakang pelatihan-pelatihan yang pernah diikuti, dan dari keterampilan / pengalaman yang dinyatakan dalam pelaksanaan tugas. Variabel kapasitas sumber daya manusia diukur dengan menggunakan delapan pernyataan. Masing-masing item pernyataan tersebut kemudian diukur dengan menggunakan Skala Likert 5 point.

Teknologi informasi selain sebagai teknologi komputer (hardware dan software) untuk pemrosesan dan penyimpanan informasi, juga berfungsi sebagai teknologi komunikasi untuk penyebaran informasi. Teknologi informasi meliputi komputer (mainframe, mini, micro), perangkat lunak (software), database, jaringan (internet, internet), electronic commerce, dan jenis lainnya yang berhubungan dengan teknologi (Wilkinson et al., 2000). Variabel ini diukur dengan instrument yang diadopsi dari Goodhue dan Thompson (1991) dan dikembangkan oleh Jurnaldi dan Supomo (2002). Pemanfaatan Teknologi Informasi diukur dengan menggunakan delapan pernyataan.

Peraturan Pemerintah Republik Indonesia Nomor 65 Tahun 2010 tentang Sistem Informasi Keuangan Daerah (SIKD) menyebutkan bahwa Sistem Informasi Keuangan Daerah adalah sustu sistem yang mendokumentasikan, mengadministrasikan, serta mengolah data pengelolaan keuangan daerah dan data terkait lainnya menjadi informasi yang disajikan kepada masyarakat dan sebagai bahan pengambilan keputusan dalam rangka perencanaan, 
pelaksanaan, dan pelaporan pertanggungjawaban pemerintah daerah. Sedangkan penerapan akuntansi keuangan daerah adalah penerapan sistem informasi akuntansi tesebut oleh masing-masing satuan kerja perangkat daerah dalam proses penyusunan laporan keuangan pemerintah daerah diukur dengan sepuluh pernyataan.

Kualitas laporan keuangan yang dimaksud dalam penelitian ini adalah taraf (mutu) atau terpenuhinya kriteria atau harapan yang melekat pada informasi laporan keuangan (Wilkinson, 2000:18). Kriteria yang dipakai untuk mengukur kualitas informasi laporan keuangan adalah dimensi relevan, andal, dapat diperbandingkan dan dapat dipahami (PP No. 71 Tahun 2010, . Indikator masing-masing dimensi adalah sebagai berikut: (a) dimensi relevan dengan indikator memiliki umpan balik (feedback value), memiliki manfaat prediktif (peramalan), tepat waktu dan lengkap; (b) dimensi andal dengan indikator penyajian yang jujur, dapat diverifikasi (verifiability), netralitas; (c) dimensi dapat diperbandingkan dengan indikator konsisten penerapan kebijakan akuntansi, informasi yang termuat dalam laporan keuangan dapat dibandingkan dengan laporan keuangan periode sebelumnya; (d) dimensi dapat dipahami dengan indikator bentuk dan istilah informasi laporan keuangan disesuaikan dengan batas pemahaman para pengguna. Kualitas informasi laporan keuangan daerah diukur dengan menggunakan sebelas pernyataan. Masing-masing item pernyataan tersebut kemudian diukur dengan menggunakan Skala Likert 5 point.

\section{Hasil dan pembahasan}

Pengujian validitas dilakukan untuk menguji apakah pertanyaan/pernyataan dalam kuesioner telah sesuai mengukur konsep yang dimaksud. Pengujian validitas dalam penelitian ini menggunakan Pearson Correlation yaitu dengan cara menghitung korelasi antara skor masing-masing butir pernyataan dengan skor total. Jika korelasi antara skor masing-masing butir pernyataan dengan skor total mempunyai tingkat signifikansi $<0,05$ maka butir pernyataan tersebut dinyatakan valid dan sebaliknya.

Berikut ini adalah hasil uji validitas atas kapasitas sumber daya manusia (X1), pemanfaatan teknologi informasi (X2), penerapan sistem akuntansi keuangan daerah (X3), dan kualitas laporan keuangan daerah $(\mathrm{Y})$, memiliki kriteria valid dengan nilai signifikansi < 0,005 . Hal ini berarti semua item pernyataan yang digunakan dalam penelitian ini mampu diungkapkan dalam kuesioner tersebut.

Uji reliabilitas dilakukan dengan metode internal consistency. Jika nilai koefisien alpha > 0,60 maka disimpulkan bahwa intrumen penelitian tersebut handal atau reliable (Ghozali, 2005). Hasil pengujian reliabilitas dalam penelitian ini menunjukkan nilai Cronbach's Alpha untuk variabel kapasitas sumber daya manusia 0,851; pemanfaatan teknologi informasi 0,819; penerapan sistem akuntansi keuangan daerah 0,920; dan kualitas laporan keuangan daerah 0,796 Dengan demikian dapat disimpulkan bahwa pernyataan dalam kuesioner ini reliable karena memiliki nilai Cronbach's Alpha $>0,60$. Hal ini menunjukkan bahwa apabila pernyataan diajukan kembali akan diperoleh jawaban yang relatif sama dengan jawaban sebelumnya.

Uji normalitas dilakukan untuk mengetahui data berdistribusi normal. Uji normalitas dalam penelitian ini dengan menggunakan grafik P-Plot SPSS. Melalui grafik P-Plot dapat dinilai dari titik-titik penyebaran disekitar garis diagonal apakah searah dan mengikuti garis diagonal. Berdasarkan uji normalitas dengan grafik P-Plot SPSS, didapatkan bahwa titik data menyebar di sekitar garis diagonal dan penyebaran titik-titik data searah mengikuti garis diagonal. Dengan demikian model regresi telah memenuhi asumsi normalitas.

Pengujian multikolinieritas dilakukan untuk melihat apakah pada model regresi ditemukan adanya korelasi antara variabel independen. Cara mendeteksinya adalah dengan melihat nilai tolerance dan nilai Variance Inflation Factor (VIF). Jika nilai VIF $<10$ dan 
tolerance $>$ 0,1 maka variabel independen terbebas dari persoalan multikolinieritas. Hasil uji SPSS menunjukkan

bahwa semua nilai tolerance $>0,1$ dan nilai $\mathrm{VIF}<10$. Hasil uji SPSS menunjukkan bahwa semua nilai tolerance $>0,1$ dan nilai $\mathrm{VIF}<10$. Hal ini menunjukkan bahwa semua variabel independen terbebas dari multikolinieritas.

Uji heterokedastisitas dilakukan untuk mengetahui apakah dalam sebuah model regresi terjadi ketidaksamaan varians dari residual suatu pengamatan ke pengamatan lain. Ada tidaknya heteroskedastisitas dapat ditentukan dengan melihat grafik plot antara nilai prediksi variabel terikat dengan residual. Jika grafik plot menunjukkan suatu pola titik yang bergelombang atau melebar kemudian menyempit, maka dapat disimpulkan bahwa telah terjadi heteroskedastisitas. Namun jika tidak ada pola yang jelas, yaitu serat titik-titik menyebar di atas dan di bawah angka 0 pada sumbu $Y$, maka tidak terjadi heteroskedastisitas. Hasil uji menunjukkan bahwa pada scatterplot, titik-titik yang ada tidak membentuk sebuah pola namun menyebar, sehingga dapat disimpulkan bahwa dalam penelitian tidak terjadi heterokedastisitas.

Pengujian uji asumsi klasik dalam penelitian ini telah dipenuhi untuk selanjutnya dilakukan pengujian analisis regresi berganda. Model regresi berganda dalam penelitian ini adalah untuk menguji pengaruh kapasitas sumber daya manusia $\left(X_{1}\right)$, pemanfaatan teknologi informasi $\left(X_{2}\right)$ dan penerapan sistem akuntansi keuangan daerah $\left(X_{3}\right)$ terhadap kualitas laporan keuangan $(\mathrm{Y})$.

Hasil analisis regresi berganda pada tabel 1.

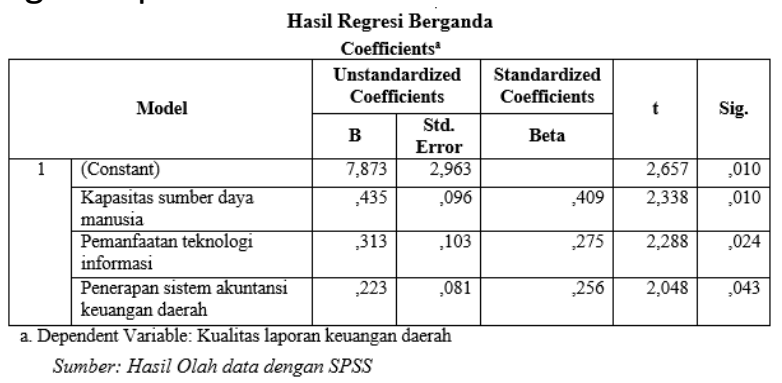

Berdasarkan tabel 1, diperoleh persamaan regresi berganda sebagai berikut :

$$
Y=7,873+0,435 X_{1}+0,313 X_{2}+0,223 X_{3}+e
$$

Persamaan regresi berganda di atas dapat dijelaskan sebagai berikut.

1. Kualitas laporan keuangan $(\mathrm{Y})$ berhubungan positif atau searah dengan kapasitas sumber daya manusia $\left(X_{1}\right)$, pemanfaatan teknologi informas $\left(X_{2}\right)$ dan penerapan sistem akuntansi keuangan daerah $\left(\mathrm{X}_{3}\right)$.

2. Variabel kapasitas sumber daya manusia menunjukkan bahwa kapasitas sumber daya manusia memiliki pengaruh positif terhadap kualitas laporan keuangan daerah dilihat dari nilai koefisien regresi sebesar 0,435. Hal ini menunjukan bahwa semakin baik kapasitas sumber daya manusia maka kualitas laporan keuangan daerah semakin baik.

3. Variabel pemanfaatan teknologi informasi menunjukkan bahwa pemanfaatan teknologi informasi memiliki pengaruh positif terhadap kualitas laporan keuangan daerah dilihat dari nilai koefisien regresi sebesar 0,313. Hal ini menunjukkan bahwa pemanfaatan teknologi informasi yang baik maka kualitas laporan keuangan daerah akan semakin baik.

4. Variabel penerapan sistem akuntansi keuangan daerah menunjukkan bahwa sistem akuntansi keuangan daerah memiliki pengaruh positif terhadap kualitas laporan keuangan daerah dilihat dari nilai koefisien regresi sebesar 0,223. Hal ini menunjukkan bahwa penerapan sistem akuntansi keuangan daerah yang baik maka kualitas laporan keuangan daerah akan semakin baik. 
Nilai intersep sebesar 7,873 menunjukkan bahwa apabila kapasitas sumber daya manusia, pemanfaatan teknologi informasi dan penerapan sistem akuntansi keuangan daerah dianggap konstan, maka kualitas laporan keuangan daerah akan meningkat sebesar 7,873 satuan.

Pengujian hipotesis secara simultan (uji F) dilakukan untuk menunjukkan apakah semua variabel independen yang digunakan dalam model regresi mempunyai pengaruh yang signifikan secara bersama-sama terhadap variabel dependen. Hasilnya dapat dilihat pada tabel 2.

\begin{tabular}{|c|c|c|c|c|c|c|}
\hline \multicolumn{7}{|c|}{ ANOVAa } \\
\hline \multicolumn{2}{|l|}{ Model } & $\begin{array}{l}\text { Sum of } \\
\text { Squares }\end{array}$ & Df & $\begin{array}{l}\text { Mean } \\
\text { Square }\end{array}$ & $\mathbf{F}$ & Sig. \\
\hline \multirow[t]{3}{*}{1} & Regression & 769.476 & 3 & 256.492 & 49.252 & $.000^{\mathrm{b}}$ \\
\hline & Residual & 400.993 & 77 & 5.208 & & \\
\hline & Total & 1170.469 & 80 & & & \\
\hline
\end{tabular}

Berdasarkan hasil pengolahan data pada tabel 2, menunjukkan bahwa $F_{\text {hitung }}=49,252$ sehingga $F_{\text {hitung }}=49,252>F_{\text {tabel }}=2,31$ maka Ha diterima dan Ho ditolak. Dilihat dari nilai signifikansi, tabel 5.12 menunjukkan bahwa nilai signifikansi adalah 0,000<0,005 sehingga Ha diterima dan Ho ditolak.

Hasil pengujian ini menunjukkan bahwa seluruh variabel independen yaitu kapasitas sumber daya manusia, pemanfaatan teknologi informasi dan penerapan sistem akuntansi keuangan daerah berpengaruh secara signifikan terhadap variabel dependen yaitu kualitas laporan keuangan daerah.

Pengujian hipotesis secara parsial dilakukan melalui uji t untuk mengetahui besarnya pengaruh masing-masing variabel independen secara individual terhadap variabel dependen. Hasil uji t ini pada output SPSS 20 dapat dilihat pada tabel 1.

Penjelasan dari hasil uji parsial adalah sebagai berikut :

1. Pengaruh kapasitas sumber daya manusia terhadap kualitas laporan keuangan daerah

a. Nilai $t_{\text {hitung }}$ dari variabel kapasitas sumber daya manusia adalah 4,523 sehingga: $t_{\text {hitung }}=4,523>t_{\text {tabel }}=1.99125$

b. Signifikansi dari variabel kapasitas sumber daya manusia adalah sebesar 0,015 <0,05.

c. Hal ini menunjukkan bahwa $\mathrm{Ha}_{1}$ diterima dan $\mathrm{Ho}_{1}$ ditolak, sehingga terbukti bahwa kapasitas sumber daya manusia berpengaruh positif dan signifikan terhadap kualitas laporan keuangan daerah.

2. Pengaruh pemanfaatan teknologi informasi terhadap kualitas laporan keuangan daerah

a. Nilai $t_{\text {hitung }}$ dari variabel pemanfaatan teknologi informasi adalah 2,288 sehingga: $t_{\text {hitung }}=3,046>t_{\text {tabel }}=1.99125$

b. Signifikansi dari variabel pemanfaatan teknologi informasi adalah sebesar $0,025<$ 0,05 .

c. Hal ini menunjukkan bahwa $\mathrm{Ha}_{2}$ diterima dan $\mathrm{Ho}_{2}$ ditolak, sehingga terbukti bahwa pemanfaatan teknologi informasi berpengaruh positif dan signifikan terhadap kualitas laporan keuangan daerah.

3. Pengaruh penerapan sistem akuntansi keuangan daerah terhadap kualitas laporan keuangan daerah

a. Nilai $t_{\text {hitung }}$ dari variabel penerapan sistem akuntansi keuangan daerah adalah 2,048 sehingga:

$t_{\text {hitung }}=2,758>t_{\text {tabel }}=1.99125$

b. Signifikansi dari variabel penerapan sistem akuntansi keuangan daerahadalah sebesar $0,023<0,05$. 
c. Hal ini menunjukkan bahwa $\mathrm{Ha}_{3}$ diterima dan $\mathrm{Ho}_{3}$ ditolak, sehingga terbukti bahwa penerapan sistem akuntansi keuangan daerah berpengaruh positif dan signifikan terhadap kualitas laporan keuangan daerah.

Uji koefisien determinasi dalam regresi linear berganda, untuk regresi dengan lebih dari dua variabel bebas digunakan adjusted R2 sebagai koefisien determinasi. Berdasarkan hasil uji, nilai adjusted R2 adalah 0,644 yang artinya kualitas laporan keuangan daerah sebesar $64,4 \%$ dipengaruhi oleh kapasitas sumber daya manusia, pemanfaatan teknologi informasi dan penerapan sistem akuntansi keuangan daerah sedangkan sisanya 35,6\% dipengaruhi oleh faktor lain diluar penelitian ini.

\section{Pengaruh kapasitas sumber daya manusia terhadap kualitas laporan keuangan daerah}

Pengujian hipotesis pertama menunjukkan bahwa pada variabel kapasitas sumber daya manusia, $t_{\text {hitung }}=3,046>t_{\text {tabel }}=1.99125$ sehingga kapasitas sumber daya manusia berpengaruh positif dan signifikan terhadap kualitas laporan keuangan daerah Kabupaten Minahasa Selatan. Nilai koefisien regresi kapasitas sumber daya manusia sebesar 0.015 . Hal ini berarti bahwa semakin baik kapasitas sumber daya manusia maka kualitas laporan keuangan daerah semakin baik.

Griffin (2004) yang menyatakan bahwa sumber daya manusia dapat diukur melalui tanggung jawab, pelatihan dan tingkat pengalaman. Pendidikan merupakan suatu kegiatan yang universal dalam kehidupan manusia. Pelatihan adalah proses sistematis mengubah tingkah laku sesorang untuk mencapai tujuan organisasi. Pelatihan yang baik, harus berkaitan dengan keahlian dan kemampuan untuk melaksanakan pekerjaanya. Pengalaman dilihat dari lamanya seseorang bekerja. Dengan pengalaman, seseorang akan terbiasa melakukan suatu pekerjaan dan mempunyai wawasan yang luas serta mudah beradaptasi dengan lingkungan. Disamping itu kebijakan-kebijakan yang dilakukan oleh pemerintah daerah cukup menunjang, antara lain dengan mengadakan pertemuan-pertemuan antar SKPD yang membicarakan mengenai persoalan-persoalan tentang keuangan. Penulis juga melihat besarnya keinginan dan harapan para pegawai keuangan di Pemda ini untuk mampu menyusun laporan keuangan sesuai dengan aturan yang berlaku.

\section{Pengaruh pemanfaatan teknologi informasi terhadap kualitas laporan keuangan daerah}

Pengujian hipotesis kedua menunjukkan bahwa pada variabel pemanfaatan teknologi informasi, $t_{\text {hitung }}=3,046>t_{\text {tabel }}=1.99125$ sehingga variabel pemanfaatan teknologi informasi berpengaruh positif dan signifikan terhadap kualitas laporan keuangan daerah Kabupaten Minahasa Selatan. Nilai koefisien regresi variabel pemanfaatan teknologi informasi sebesar 0,025 . Hal ini dapat diartikan semakin baik pemanfaatan teknologi informasi yang dilakukan oleh SKPD di Pemerintah Kabupaten Minahasa Selatan, maka akan semakin baik pula kualitas laporan keuangan daerah.

Hasil penelitian ini mendukung teori keagenan, Jensen dan Meckling (Jensen, 1976) mendefinisikan hubungan keagenan sebagai sebuah kontrak dimana satu atau lebih (principal) menyewa orang lain (agent) untuk melakukan beberapa jasa untuk kepentingan mereka dengan mendelegasikan beberapa wewenang pembuatan keputusan kepada agen. Hal ini menunjukkan bahwa semakin baik pemanfaatan teknologi informasi maka semakin baik pula kualitas laporan keuangan daerah pemerintah daerah.

Hal ini disebabkan Pemerintah Kabupaten Minahasa Selatan telah memanfaatkan teknologi informasi seperti komputer, dan software akuntansi berupa Sistem Informasi Manajemen Daerah (SIMDA) sehingga memudahkan pegawai pengelola keuangan dalam menyusun laporan keuangan. Dengan menggunakan teknologi informasi tersebut informasi 
keuangan yang dihasilkan dapat lebih akurat dan disajikan tepat waktu. Perlu menjadi perhatian pemerintah Daerah untuk lebih memberikan dorongan kepada para ASN pengelola keuangan meningkatkan penggunaan teknologi informasi karena akan menjadi percuma jika teknologi informasi yang sudah mendukung sesuai dengan peraturan pemerintah (hardware, software) tetapi tidak didukung dengan (brainware) yang memadai.

\section{Pengaruh penerapan sistem akuntansi keuangan daerah terhadap kualitas laporan keuangan daerah}

Hasil pengujian hipotesis ketiga menunjukkan bahwa pada variabel penerapan sistem akuntansi keuangan daerah, $t_{\text {hitung }}=2,048>t_{\text {tabel }}=1.99125$ sehingga penerapan sistem akuntansi keuangan daerah berpengaruh signifikan positif terhadap kualitas laporan keuangan daerah Kabupaten Minahasa Selatan. Nilai koefisien regresi variabel penerapan sistem akuntansi keuangan daerah sebesar 0,023. Hal ini dapat diartikan bahwa penerapan sistem akuntansi keuangan daerah baik maka kualitas laporan keuangan daerah akan semakin baik.

Jika sistem akuntansi keuangan daerah sudah diterapkan dengan baik oleh SKPD pada Pemerintah Kabupaten Minahasa Selatan, maka kualitas laporan keuangan daerah pun akan semakin baik. Karena pada dasarnya sistem akuntansi adalah suatu kesatuan yang apabila tidak diterapkan atau ada satu bagian sistem yang tidak diterapkan maka sulit untuk memperoleh karakteristik kualitatif laporan keuangan daerah sesuai SAP yakni relevan, andal, dapat dipahami, dan dapat dibandingkan. Peraturan Pemerintah Republik Indonesia Nomor 65 Tahun 2010 tentang Sistem Informasi Keuangan Daerah (SIKD). Informasi keuangan daerah adalah segala informasi yang berkaitan dengan keuangan daerah yang diperlukan dalam rangka penyelenggaraan sistem informasi keuangan daerah.

Dari hasil penelitian memberikan bukti bahwa dengan adanya kejelasan standar akuntansi pemerintahan yang dipakai, maka akan dihasilkan laporan keuangan yang berkualitas. Sistem akuntansi keuangan daerah menjadi acuan yang digunakan ASN Kabupaten Minahasa Selatan dalam menyusun laporan keuangan pemerintah Kabupaten Minahasa Selatan, sehingga tujuan organisasi untuk memberikan laporan keuangan pemerintah daerah sesuai dengan PP 71 tahun 2010 yang: Relevan, Andal, Dapat dibandingkan, Dapat dipahami. Dapat terwujud untuk mendapatkan opini WTP.

\section{Kesimpulan dan saran}

Berdasarkan hasil penelitian diperoleh kesimpulan sebagai berikut:

1. Kapasitas sumber daya manusia berpengaruh secara positif dan signifikan terhadap kualitas laporan keuangan daerah Kabupaten Minahasa Selatan.

2. Pelaksanaan pemanfaatan teknologi informasi berpengaruh secara positif dan signifikan terhadap kualitas laporan keuangan daerah Kabupaten Minahasa Selatan.

3. Penerapan sistem akuntansi keuangan daerah berpengaruh secara positif dan signifikan terhadap kualitas laporan keuangan daerah Kabupaten Minahasa Selatan.

Saran untuk pemerintah Kabupaten Minahasa Selatan:

1. Dalam rangka peningkatan kapasitas sumber daya manusia di tiap-tiap SKPD Kabupaten Minahasa Selatan sebaiknya sesuai dengan prinsip the right man in the right place dimana dalam penempatan pegawai didasarkan pada klasifikasi pendidikan sesuai dengan job description sehingga lebih mempermudah proses pelaporan keuangan daerah, juga untuk lebih ditingkatkan pelatihan agar supaya dapat menjalankan fungsi dan kewenangannya untuk mencapai tujuan yakni kualitas laporan keuangan yang baik.

2. Perlu penambahan perangkat/peralatan komputer sesuai dengan PP no 65 tahun 2010 hal ini diperlukan untuk mengatur terkait batas waktu pelaporan pertanggungjawabaan 
sehingga penyampaian laporan yang tertunda apabila terlambat dalam melakukan penyampaian, perawatan komputer serta jaringannya untuk lebih mempermudah dalam proses pelaporan keuangan yang baik sehingga tercapai tujuan yakni kualitas laporan keuangan yang baik.

Komitmen dan konsistensi pimpinan sangat diperlukan dalam penerapan sistem akuntansi keuangan daerah di Kabupaten Minahasa Selatan sebaiknya dilaksanakan sesuai dengan PP 65 tahun 2010 sehingga menghasilkan laporan keuangan relevan, andal, dapat dipahami dan dapat dibandingkan

\section{Daftar Pustaka}

Abdullah, Syukriy, Abdul Halim. 2006. Hubungan dan Masalah Keagenan di Pemerintah Daerah (Sebuah Peluang Penelitian Anggaran dan Akuntansi). Jurnal Akuntansi Pemerintah, Volume 2 No. 1, November.

BPK. 2016. Ikhtisar Hasil Pemeriksaan Semester I Tahun 2016. Buku Laporan Keuangan

Chan, James L. 2003. Government Accounfsting: An Assessment of Theory, Purposes and Standards. Public Money And Management January 2003.

Ghozali, Imam, 2006. Aplikasi Analisis Multivarite dengan SPSS, Cetakan Keempat, Badan Penerbit Universitas Diponegoro, Semarang.

Goodhue Dale L, Thompson Ronald L. 1995. Task-technology fit and individual performance. MIS Quarterly; Jun 1995; 19, 2; ABI/INFORM.

Griffin. 2004. Manajemen, alih bahasa Gina Gania, Erlangga, Jakarta

Halim Abdul \& Syam Kusufi. 2012. Akuntansi Sektor Publik : Teori, Konsep dan Aplikasi. Salemba Empat : Jakarta.

Ikatan Akuntan Indonesia. 2012. Standar Akuntansi Keuangan. PSAK. Cetakan Keempat, Buku Satu, Jakarta: Salemba Empat.

Jensen Michael C, William H. Meckling. Theory Of The Firm: Managerial Behavior, Agency Costs And Ownership Structure Journal of Financial Economics 3 (1976) 305-360. Q NorthHolland Publishing Company.

Jurnali Teddy dan Bambang Supomo. 2002. Pengaruh Faktor-Faktor Kesesuaian Tugas Teknologi dan Pemanfaatan Teknologi Informasi terhadap Kinerja Akuntan Publik. Jurnal Riset Akuntansi Indonesia Vol.5.No.2

Kadir Ahmad. 2006. Pengenalan Teknologi Informasi. Yogyakarta: Andi Publisher.

Mahmudi. 2011. Manajemen Keuangan Daerah. Jakarta: Erlangga.

Mardiasmo. 2012. Akuntansi Sektor Publik. Penerbit Andi. Yogyakarta.

Peraturan Pemerintah Republik Indonesia Nomor 71 tahun 2010 tentang Standar Akuntansi Pemerintahan.

--- Nomor 65 tahun 2010 tentang Perubahan Atas Peraturan Pemerintah Nomor 56 tahun 2005 tentang Sistem Informasi Keuangan Daerah.

Sugiyono. 2015. Metode Penelitian Kuantitatif, Kualitatif dan R\&D. AlfaBeta.

Suwardjono. 2005. Teori Akuntansi: Perekayasaan Pelaporan Keuangan (Edisi III). Yogyakarta: BPFE.

Tangkilisan Hessel Nogi S. 2005. Manajemen Publik. Grasindo.

Tjiptoherijanto, Prijono, 1998, Kinerja SDM dan Manajemen Perubahan (dalam Majalah Profesi).

Undang-Undang Republik Indonesia Nomor 17 tahun 2003 tentang Keuangan Negara.

--- Nomor 32 Tahun 2003 tentang Pemerintah Daerah.

--- Nomor 33 Tahun 2004 tentang Perimbangan antara Pemerintah Pusat dan Pemerintah Daerah. 
Van Beest., G. Braam, and S. Boelens. 2009. Quality of Financial Reporting: Measuring Qualitative Characteristic. Nijmegen Center for Economics (NiCE) Institute for Management Research Radboud University Nijmegen. NiCe Working Paper.

Wilkinsons, Hilton And Warren, S.Carl., And Reeve, M.James., And Fess, E.Philip. 2005. Corporate Financial Accounting. South Western: Thomson. 